\title{
Guidelines
}

\section{Diagnosis and Management of Chronic Obstructive Pulmonary Disease: The Swiss Guidelines}

\author{
Official Guidelines of the Swiss Respiratory Society
}
E.W. Russia ${ }^{a}$ W. Karrer ${ }^{d}$
M. Brutsche $e^{\mathrm{e}}$
C. Eich ${ }^{b}$
J.W. Fitting ${ }^{i}$
M. Frey ${ }^{f} \quad$ T. Geiser ${ }^{j}$
M. Kuhn ${ }^{9}$
L. Nicod ${ }^{i}$
F. Quadrih
T. Rochat ${ }^{k}$
C. Steurer-Stey ${ }^{\mathrm{C}}$
D. Stolz'

a Pulmonary Division, Department of Internal Medicine, University Hospital Zurich, ${ }^{b}$ Private Practice, and 'Institut für Hausarztmedizin, Zurich, d Luzerner Höhenklinik, Montana, ${ }^{\mathrm{C} K a n t o n s s p i t a l ~ S t . ~ G a l l e n, ~ S t . ~ G a l l e n, ~}$ ${ }^{f}$ Klinik Barmelweid, Barmelweid, ${ }^{9}$ Kantonsspital Graubünden, Chur, hOspedale Regionale Bellinzona e Valli, Bellinzona, and Pulmonary Divisions of the University Hospitals of 'Lausanne, ${ }^{\mathrm{j}}$ Bern, ${ }^{\mathrm{k}} \mathrm{Geneva}$, and 'Basel, Switzerland

\section{Key Words}

Chronic obstructive pulmonary disease $\cdot$ Diagnosis •

Treatment $\cdot$ Management $\cdot$ Swiss Guidelines

\begin{abstract}
The new Swiss Chronic Obstructive Pulmonary Disease (COPD) Guidelines are based on a previous version, which was published 10 years ago. The Swiss Respiratory Society felt the need to update the previous document due to new knowledge and novel therapeutic developments about this prevalent and important disease. The recommendations and statements are based on the available literature, on other national guidelines and, in particular, on the GOLD (Global Initiative for Chronic Obstructive Lung Disease) report. Our aim is to advise pulmonary physicians, general practitioners and other health care workers on the early detection and diagnosis, prevention, best symptomatic control, and avoidance of COPD as well as its complications and deterioration.
\end{abstract}

\section{KARGER}

Fax +41613061234

E-Mail karger@karger.com

www.karger.com
C) 2013 S. Karger AG, Basel

$0025-7931 / 13 / 0852-0160 \$ 38.00 / 0$

Accessible online at:

www.karger.com/res

\section{Introduction}

Chronic obstructive pulmonary disease (COPD) is a leading cause of chronic morbidity and mortality throughout the world. Its prevalence and its social as well as economic burden are increasing, due, in part, to the aging of the population. According to the global BOLD (Burden of Obstructive Lung Disease) study, COPD is projected to rank fifth worldwide as cause of death in the year 2020 [1]. COPD is related, in many cases but not exclusively, to cigarette smoking, and in some areas of the world with large populations, air pollution resulting from the burning of biomass fuels has been identified as a relevant risk factor $[2,3]$.

Over the past years, the COPD guidelines of various national and professional associations have been revised [4-7] and in December 2011, 10 years after its first release, the third and updated version of the GOLD (Global Initiative for Chronic Obstructive Lung Disease) report became available [8]. Our current guidelines are based on a 
previous version, 2002 [9], and consider new knowledge and novel developments. They aim to advise pulmonary physicians, general practitioners and other healthcare workers on early detection and diagnosis, prevention, best symptomatic control, avoidance of complications and deterioration of COPD.

\section{Definition}

COPD is characterized by chronic airflow limitation and a range of pathological changes in the lung, significant extrapulmonary effects and important comorbidities, which may contribute to the severity of the disease in individual patients (GOLD, updated 2011) [8]. The chronic airflow limitation is caused by an individual mixture of small airway disease (obstructive bronchiolitis) and parenchymal destruction (emphysema). Chronic bronchitis is a clinical and epidemiological term and is defined by a history of cough and mucus production on most days for at least 3 months a year over at least 2 successive years. Not all patients with chronic bronchitis have COPD, and not all patients with COPD suffer from the symptoms of chronic bronchitis.

\section{Pathophysiology}

The major risk factors for the development of COPD are inhaled toxic substances, particularly tobacco smoke and the products from the burning of biomass fuels that cause inflammation of the lungs. The inflammation can lead to tissue damage if the normal protective and/or repair mechanisms are overwhelmed or defective. The results of the lung tissue damage are mucus hypersecretion, airway narrowing, fibrosis, destruction of the parenchyma and vascular changes. These pathological changes lead to airflow limitation, loss of elastic recoil and other physiological abnormalities. The inflammation in COPD is markedly different from that in asthma. However, some patients with COPD also have asthma and the inflammation in their lungs may show the characteristics of both diseases. Since inflammation is a feature of COPD, specific anti-inflammatory therapies may have beneficial effects in controlling symptoms, preventing exacerbations and slowing disease progression. However, the response of inflammation to corticosteroids in COPD is poor, contrary to their effectiveness in asthma.

\section{Risk Factors}

COPD arises from an interaction of both host factors and environmental exposures. Smoking remains a leading cause for COPD. It is estimated that in industrialized countries, in men about $80 \%$ and in women around $60 \%$ of the COPD mortality is attributable to smoking, whereas in developing countries smoking contributes to only about $45 \%$ in men and $20 \%$ in women $[10,11]$. In unindustrialized countries biomass fuel utilization for cooking and heating at home is an important environmental factor. Other factors may include occupational exposures, passive smoking and outdoor air pollution. The population-attributable fraction for the workplace contribution to COPD risk has been estimated to be $15-20 \%$ in Europe and North America [10]. The risk in less-regulated areas of the world is likely to be much higher. In the SAPALDIA study (Swiss study on Air Pollution And Lung Disease in Adults), high levels of occupational exposure to biological dusts, mineral dusts, gases or fumes, as determined from self-reports, were found to be associated with an increased incidence of COPD of GOLD stage II or higher [12].

Host factors include genetics, epigenetics and other characteristics of the host such as bronchial hyperreactivity and a history of asthma [13] as well as a history of severe respiratory infection in childhood. Inherited $\alpha-1$ antitrypsin deficiency is a single-gene autosomal recessive disease that predisposes to COPD, but this accounts for less than 1\% of all cases of COPD [14, 15]. Apart from this particular gene, genetic predisposition to COPD is very complex and is incompletely understood at present. COPD has been associated with the polymorphisms of various genes, but very few of these associations have been replicated in more than 2 or 3 independent population samples [16]. Other factors may also predispose to the development of COPD. Bronchial hyperreactivity is a risk factor, even after exclusion of asthmatics [17, 18], and chronic bronchitis symptoms seem to increase the risk for the later development of COPD [19, 20].

\section{Epidemiology and Burden of Disease}

COPD prevalence data show remarkable variation due to differences in survey methods and diagnostic criteria. The BOLD study reports a variability between countries in the prevalence of GOLD stage II-IV COPD [21], ranging from $9 \%$ in Iceland to $19 \%$ in the Philippines for male subjects of more than 40 years of age. 
Country-specific age distributions, smoking prevalence rates and other important environmental factors may contribute to most of these disparities. In Switzerland, in a sample of 6,126 subjects (SAPALDIA), the prevalence of COPD of GOLD stage II or higher was $5.1 \%$ in the population aged 30-73 years, and the prevalence of GOLD stage I or higher was 10\% [22]. Prevalence was strongly dependent on age. Consequently, extrapolated to a resident population of 7.8 million in Switzerland (2010 census), the estimated number of stage II or higher ranges between 200,000 and 300,000 , and that for stage I or higher is about 400,000 .

\section{Assessment}

\section{Clinical Assessment}

Although it is an important part of patient care, physical examination has a low sensitivity and specificity for the detection or exclusion of mild to moderately severe forms of COPD. If the physical signs of airflow obstruction and pulmonary hyperinflation are present, the patient usually suffers from an advanced stage of the disease. The leading symptoms of COPD are shortness of breath during exercise, exercise limitation and chronic cough [23]. The degree of dyspnea can be assessed by the Modified Medical Research Council (mMRC) questionnaire [24] (table 1). The COPD Assessment Test [25] has a broader coverage of the impact of COPD on the patient's daily life and well-being and correlates closely with health status measured using the St. Georges Respiratory questionnaire. The test has been translated into several languages, contains 8 items and can be easily performed on the internet www.catestonline.org (table 2). Another important element of a patient's history is the occurrence and frequency of exacerbations. An exacerbation of COPD is defined as an acute event characterized by a worsening of the patient's respiratory symptoms that is beyond normal day-to-day variations and leads to a change in medication. The exacerbation rate varies greatly between patients. The best predictor of frequent exacerbations ( $\geq 2$ per year) is a history of previous exacerbations and the severity of COPD [26]. Since COPD often develops in middle-aged long-time smokers, patients frequently have a variety of other diseases related to either smoking or aging. Comorbidities that occur frequently in COPD patients include cardiovascular disease, skeletal muscle dysfunction, metabolic syndrome, osteoporosis, lung cancer and depression [27]. The comprehensive assessment of a patient with COPD forms the basis for ther-
Table 1. mMRC scale

$0 \quad$ No breathlessness, except during strenuous exercise.

1 Shortness of breath when hurrying on the level or walking up a slight hill.

2 Walk slower than people of the same age on the level because of breathlessness, or have to stop for breath when walking at own pace on the level.

3 Stop for breath after walking $100 \mathrm{~m}$ or after a few minutes on the level.

4 Too breathless to leave the house or breathlessness from dressing or undressing. apy and combines the symptomatic assessment with the patient's spirometric classification and/or the risk of exacerbations.

The degree of airflow obstruction, as assessed by the $\mathrm{FEV}_{1}$, is but one of the essential prognostic features of COPD. Several studies have shown that, in addition, the severity of dyspnea, walking distance and body mass index (BMI; see BODE index, table 3) correlate best with life expectancy in COPD [28].

\section{Pulmonary Function Testing}

Lung function should be tested in patients with symptoms of COPD such as chronic cough, wheezing, shortness of breath and limitation on exertion. Clinicians should, however, be alert to the fact that some patients may deny exercise limitation because they have spontaneously reduced their habitual level of activity [29]. Spirometry is the gold standard to assess the presence and degree of airflow obstruction. The abnormalities consist of a reduction in $\mathrm{FEV}_{1}$ and in the ratio of $\mathrm{FEV}_{1}$ to the forced vital capacity (FVC). Small, handheld spirometers are convenient to use, have a graphic display, and store and print the numeric results as well as the flow-volume curve or the spirogram of the patient. Office spirometry should be performed in primary care by well-trained personnel [30, 31]. In COPD, the correlation between peak expiratory flow (PEF) and $\mathrm{FEV}_{1}$ is poor. Therefore, the measurement of PEF, well established in the management of asthma, should not be used in patients with COPD. The degree of airflow obstruction in COPD is classified as proposed by the GOLD (table 4). This arbitrary international staging system is intended to standardize the diagnosis of COPD by using a fixed threshold of $\mathrm{FEV}_{1} / \mathrm{FVC}<0.70$ for airflow obstruction and to grade its severity based on $\mathrm{FEV}_{1}$ as percent of predicted (\% pred.). However, since the $\mathrm{FEV}_{1} /$ 
Table 2. COPD Assessment Test

\begin{tabular}{lllllllll}
\hline & & & & & & \\
\hline I never cough & 1 & 2 & 3 & 4 & 5 & I cough all the time \\
\hline I have no phlegm (mucus) in my chest at all & 1 & 2 & 3 & 4 & 5 & My chest is completely full of phlegm (mucus) \\
\hline My chest does not feel tight at all & 1 & 2 & 3 & 4 & 5 & My chest feels very tight \\
\hline $\begin{array}{l}\text { When I walk up a hill or one flight of stairs } \\
\text { I am not breathless }\end{array}$ & 1 & 2 & 3 & 4 & 5 & $\begin{array}{l}\text { When I walk up a hill or one flight of stairs I am } \\
\text { very breathless }\end{array}$ \\
\hline I am not limited doing any activities at home & 1 & 2 & 3 & 4 & 5 & I am very limited doing activities at home \\
\hline $\begin{array}{l}\text { I am confident leaving my home despite my } \\
\text { lung condition }\end{array}$ & 1 & 2 & 3 & 4 & 5 & $\begin{array}{l}\text { I am not at all confident leaving my home because } \\
\text { of my lung condition }\end{array}$ \\
\hline \begin{tabular}{l} 
I sleep soundly \\
\hline I have lots of energy
\end{tabular} & 1 & 2 & 3 & 4 & 5 & I don't sleep soundly because of my lung condition \\
\hline
\end{tabular}

Scores and resulting impact levels: $<10=$ low; $10-20=$ medium; $21-30=$ high .

FVC ratio declines physiologically with age, using a fixed ratio of 0.70 instead of the lower limit of normal (LLN), leads to COPD overdiagnosis in older subjects, particularly for GOLD stage I. In Switzerland, the SAPALDIA study showed that among individuals classified as GOLD stage I COPD, only the subjects manifesting cough, phlegm or dyspnea had a faster decline in $\mathrm{FEV}_{1}$, increased respiratory care utilization and impaired quality of life. In contrast, asymptomatic individuals classified as having stage I COPD did not differ from subjects with normal lung function [20]. Thus, for subjects with lung function corresponding to GOLD stage I, a cautious approach would consider the diagnosis of COPD only in those manifesting symptoms of the disease. When provided by the spirometer, the use of LLN for $\mathrm{FEV}_{1} / \mathrm{FVC}$ is a physiologically sound alternative which reduces the misclassification of airway obstruction [32-34]. Since in COPD no strong correlation exists between the degree of airflow obstruction and quality of life, the revised version of GOLD emphasizes considering also the severity of shortness of breath and the frequency of exacerbations in the assessment of an individual patient [8].

Bodyplethysmography is used to measure intrathoracic gas volume for the calculation of residual volume and total lung capacity, parameters that reflect pulmonary hyperinflation. Diffusing capacity for carbon monoxide is measured by the single breath technique. These param-
Table 3. BODE index

\begin{tabular}{lcccc}
\hline Variable & \multicolumn{5}{l}{ BODE index points } \\
\cline { 2 - 5 } & 0 & 1 & 2 & 3 \\
\hline FEV $_{1}, \%$ pred. & $\geq 65$ & $50-64$ & $36-49$ & $\leq 35$ \\
Distance walked in 6 min, $\mathrm{m}$ & $\geq 350$ & $250-349$ & $150-249$ & $\leq 149$ \\
mMRC dyspnea scale & $0-1$ & 2 & 3 & 4 \\
BMI, kg/m & $>21$ & $\leq 21$ & &
\end{tabular}

Approximate 4-year survival interpretation: 0-2 = 80\%; 3-4 = $67 \% ; 5-9=57 \% ; 7-10=18 \%$.

Table 4. GOLD classification of COPD according to the degree of airflow limitation based on $\mathrm{FEV}_{1}$ after bronchodilator
GOLD I: mild GOLD II: moderate GOLD III: severe GOLD IV: very severe
$\mathrm{FEV}_{1}>80 \%$ pred. $50 \% \leq \mathrm{FEV}_{1}<80 \%$ pred. $30 \% \leq \mathrm{FEV}_{1}<50 \%$ pred. $\mathrm{FEV}_{1} \leq 30 \%$ pred. eters correlate with the degree of emphysema and it is therefore recommended that plethysmography is performed on a regular basis for follow-up in patients with severe COPD that may benefit from a lung volume reduction procedure. 
Table 5. Description of levels of evidence

\begin{tabular}{lll}
\hline $\begin{array}{l}\text { Evidence } \\
\text { category } \\
\text { evidence }\end{array}$ & Definition \\
\hline A & $\begin{array}{l}\text { Randomized controlled } \\
\text { trials (RCTs). Rich body } \\
\text { of data. }\end{array}$ & $\begin{array}{l}\text { Evidence is from end points of well-designed RCTs that provide a consistent pattern of findings } \\
\text { in the population for which the recommendation is made. Category A therefore requires a } \\
\text { substantial number of studies involving substantial numbers of participants. }\end{array}$ \\
\hline $\begin{array}{l}\text { RCTs. Limited body of } \\
\text { data. }\end{array}$ & $\begin{array}{l}\text { Evidence is from end points of intervention studies that include only a limited number of } \\
\text { RCTs, and post hoc, subgroup or meta-analysis of RCTs. } \\
\text { Category B applies when few randomized trials exist, they are small in size and the results are } \\
\text { somewhat inconsistent, or they were undertaken in a population that differs from the target } \\
\text { population of the recommendation. }\end{array}$ \\
\hline C & $\begin{array}{l}\text { Nonrandomized trials, } \\
\text { observational studies }\end{array}$ & $\begin{array}{l}\text { Evidence is from outcomes of uncontrolled or nonrandomized trials or from observational } \\
\text { studies. }\end{array}$ \\
\hline D & $\begin{array}{l}\text { Panel consensus } \\
\text { judgment }\end{array}$ & $\begin{array}{l}\text { This category is used only in case the provision of some guidance was deemed valuable, but an } \\
\text { adequately compelling clinical literature addressing the subject of the recommendation was } \\
\text { deemed insufficient to justify placement in one of the other categories. The panel consensus is } \\
\text { based on clinical experience or knowledge that does not meet the above-listed criteria. }\end{array}$ \\
\hline
\end{tabular}

\section{Chest X-Ray and Thoracic CT Scan}

A chest radiograph is indicated as part of the initial workup of patients with COPD to exclude concomitant pathologies. However, chest films are not sensitive for the detection of mild to moderate emphysema. High resolution computed tomography (HRCT) is the most sensitive and specific in vivo technique for the detection, grading and morphological characterizing of pulmonary emphysema. While CT scanning is not recommended for routine clinical assessment of COPD, it may be used to evaluate alternative diagnosis and to assess the feasibility of lung volume reduction surgery.

\section{Further Assessment}

Hypoxemia is an important problem in COPD, accentuates intolerance to physical exercise and adds to its morbidity. Exercise tests such as the 6-minute walk test or, in selected cases, spiroegometry should be performed with continuous oxygen saturation measurements. If pulsoxymetry at rest shows a saturation of $<92 \%$, an arterial blood gas analysis should be performed. If erythrocytosis is present, chronic hypoxemia should be suspected. Measurement of the $\alpha-1$ antitrypsin serum concentrations is indicated in rapidly deteriorating COPD, in COPD patients of below 45 years of age and in cases with emphysema of basal predominance. In the case of increased daytime sleepiness, oximetry at night or respiratory polygraphy may be indicated to rule out hypoxemia during sleep or an overlap syndrome (COPD and obstructive sleep apnea).

\section{Our Methodology - A Comment}

The recommendations and statements in these guidelines are based on the available literature, in particular the GOLD report [8]. A level of evidence, i.e. A, B, C or D, is indicated when available; these are listed in table 5. When evidence was lacking or international guidelines were conflicting, the authors, elected by the board of the Swiss Respiratory Society and representing chest physicians working in private practice, in hospitals and in academic medicine, reached consensus after appropriate discussion.

\section{Management of COPD}

\section{Prevention}

Identification, reduction and control of risk factors such as tobacco smoke, occupational exposure and inand outdoor pollution are important steps for preventing the development of COPD. Smoking cessation is the single most effective intervention with the greatest impact on the natural history of COPD [35, 36] (Evidence A). Brief advice by a general practitioner results in smoking cessation rates of $7.4 \%$, i.e. an increase of $2.5 \%$ over the cessation rate in a control group, and counseling of 3-10 minutes duration achieves higher cessation rates of around $12 \%$. With greater investment of time and com- 
plexity of interventions, including skills training, problem-solving and psychosocial support, the quit rate can reach $20-30 \%$ (Evidence A) [37]. In the Lung Health Study, a multicenter, controlled clinical trial, a combination of advice by a physician, group support, skills training and nicotine replacement therapy achieved quit rates of $35 \%$ at 1 year and sustained quit rates of $22 \%$ at 5 years [38]. Pharmacotherapy is effective in supporting smoking cessation attempts and at least one of these substances should be prescribed in the absence of contraindications: varenicline, bupropion SR and nicotine in various galenic preparations (Evidence A) [39-44]. Occupationally induced respiratory disorders, e.g. in farmers, can be reduced or controlled by strategies aimed at reducing the burden of inhaled particles and gases at the workplace (Evidence B) [45].

\section{Patient Education and Self-Management}

Patient education is effective in accomplishing specific goals, including smoking cessation [38] (Evidence A), initiating discussion and understanding of advanced directives and end-of-life-issues (Evidence B) [46] and improving patients' responses to exacerbations (Evidence B) [47]. In addition, elderly patients can benefit from interdisciplinary education programs. Individualized, written action plans for patients' self-management improve quality of life and decrease exacerbation recovery time by reducing patients' delay. Patient education accompanied by instruction for self-management and individualized, written action plans can improve the outcome of exacerbations [48]. Although there are studies that show a beneficial effect of disease self-management in COPD [48], a study with negative results concerning patient's self-management and COPD-related hospitalizations was recently published [49]. Quality assessment in patient instruction and survey by specially trained medical staff is therefore crucial.

\section{Pharmacologic Treatment}

None of the available medications for COPD is effective in modifying the long-term progression of airflow limitation that is the hallmark of this disease (Evidence A). Today's polypharmacy, overuse and overdose of medications constitute a significant burden on the cost of COPD management.

Official Guidelines of the Swiss

Respiratory Society

\section{Bronchodilators}

Bronchodilator medications are given on either an asneeded basis or a regular basis to prevent or reduce symptoms of COPD (Evidence A). They have the potential to improve exhalation, to reduce dynamic hyperinflation, to improve exercise performance and to decrease shortness of breath. However, they do not modify the decline of lung function or, by inference, the prognosis of the disease (Evidence B). They are given on an as-needed or regular basis depending on the COPD severity. Inhalation is the preferred means of administration. Attention to effective drug delivery and training in inhalation technique is essential. The use of metered-dose inhalers (MDI) with spacer devices, dry-powder inhalers (DPI) or nebulizers should be tailored to the patient's ability. The choice between $\beta_{2}$ agonists or anticholinergics or a combination therapy depends on the individual patient response in terms of symptom relief and side effects. Longacting inhaled bronchodilators are convenient and more effective in maintaining symptom relief than short-acting bronchodilators.

\section{Anticholinergics}

The inhibition of vagal stimulation of the bronchial tree is associated with reduced smooth muscle tone and bronchial gland secretion. The bronchodilating effect of short-acting inhaled anticholinergics lasts up to $8 \mathrm{~h}$ after administration (Evidence A). Tiotropium is a long-acting anticholinergic bronchodilator, which has to be inhaled only once daily [50]. It reduces exacerbations and related hospitalizations, and improves symptoms and health status (Evidence A) [51]. In a large, long-term clinical trial (UPLIFT) [52], there was no effect of tiotropium added to other standard therapies on the rate of lung function decline and no reduction in mortality. In another large trial, tiotropium was superior to salmeterol in reducing exacerbations, but the difference was small (Evidence A) [53].

In 2008, a meta-analysis of 17 randomized trials reported an increased risk of cardiovascular events from using anticholinergics [54]. In contrast, the UPLIFT trial [52] did not show an increased risk. An FDA-expert panel discussed these contradictory findings and concluded, based on methodological considerations, that the current data do not support the supposition that the use of tiotropium is accompanied by an increased risk of cardiovascular events [55].

\section{$\beta_{2}$ Agonists}

Sympathomimetic bronchodilators protect against bronchospasm induced by various stimuli, reduce static 
and dynamic hyperinflation and improve dyspnea, even if $\mathrm{FEV}_{1}$ remains unchanged. The effects of short-acting $\beta_{2}$ agonists (SABA: salbutamol, terbutaline or formoterol) disappear within 4-6 h. SABAs are used as rescue medication and patients are allowed to increase the number of puffs and to shorten the interval between puffs from MDI or DPI, provided it is for a short period of time (3-4 h).

The effects of long-acting inhaled $\beta_{2}$ agonists (LABA: salmeterol and formoterol) are maintained over $12 \mathrm{~h}$ or even for up to $24 \mathrm{~h}$ by the ultralong-acting bronchodilator, indacaterol, which needs to be administered only once daily $[56,57]$.

In the TORCH trial studying the combined effect of salmeterol and fluticasone [58], the lung functions, number of exacerbations and average change in clinical scores over 3 years was significantly better in the combinationtherapy group than in the group treated with salmeterol only, fluticasone only or placebo. The side effects of $\beta_{2}$ agonists are proportional to their dosage and consist mostly of tremor, some degree of tachycardia and hypokalemia especially when prescribed with diuretics.

\section{Phosphodiesterase Inhibitors}

Theophylline is a xanthine derivate and acts as a nonselective phosphodiesterase inhibitor. It has a modest bronchodilator effect in stable COPD (Evidence A) [59] and shows various physiological actions, the significance of which is disputed. Theophylline is metabolized by cytochrome P450-dependent mixed-function oxidases and many physiological variables and drugs modify its metabolism. It is less effective than and not as well tolerated as inhaled long-acting bronchodilators, and is therefore not recommended as a first-line drug.

Roflumilast is a phosphodiesterase- 4 inhibitor and has recently been approved for use in GOLD stage III and IV COPD. Its principal action is to reduce inflammation by inhibiting the breakdown of intracellular cyclic adenosine monophosphate. Roflumilast reduces moderate and severe exacerbations by $15-20 \%$ in patients with chronic bronchitis, severe to very severe COPD and a history of exacerbations (Evidence A) [60, 61]. It is a oncedaily medication and slight improvements in $\mathrm{FEV}_{1}$ are seen when it is added to long-acting bronchodilators. There are no comparison or add-on studies of roflumilast and inhaled corticosteroids (ICS). Patients have to be informed about the potential side effects i.e. diarrhea and weight loss.

\section{Glucocorticosteroids}

When considering the position of glucocorticosteroids in the management of COPD, their role during exacerbations and during stable phases (steroid trial) should be distinguished. The effects of glucocorticosteroids on airway inflammation in COPD are much less pronounced than in asthma. Based on the lack of any evidence of a long-term beneficial effect of chronic oral glucocorticoid therapy in subjects with confirmed COPD and a large body of evidence on the long-term adverse effects of this treatment, chronic treatment with oral glucocorticosteroids should be avoided in COPD (Evidence A) [62-66]. A short course of oral corticosteroids is not a reliable predictor of the long-term response to inhaled glucocorticosteroids in COPD, but can be helpful to differentiate COPD from bronchial asthma. The effect of a steroid trial should be objectively assessed based on $\mathrm{FEV}_{1}$ measurements during a stable phase of the disease (at least 6 weeks after an exacerbation) [67]. However, a short course of oral corticosteroids is indicated in COPD exacerbations.

\section{Inhaled Glucocorticosteroids}

The dose-response relationships and long-term safety of ICS in COPD are not known. Only moderate to high doses have been used in long-term clinical trials. The effects of ICS on pulmonary and systemic inflammation in patients with COPD are controversial. ICS, particularly in fixed combinations with LABA, are overused and their role should be limited to specific indications. Regular treatment with ICS does not modify the long-term decline of $\mathrm{FEV}_{1}$ or mortality in patients with COPD (Evidence A). ICS improve symptoms, lung function and quality of life, and reduce the frequency of exacerbations in COPD patients with an $\mathrm{FEV}_{1}<60 \%$ pred. (Evidence $\mathrm{A}$ ). ICS in combination with a LABA are more effective than the individual components in improving lung function, health status and reducing exacerbations when the COPD is moderate (Evidence B) to very severe (Evidence A). In summary, the use of ICS is recommended in severe and very severe COPD and in GOLD stage II COPD with an $\mathrm{FEV}_{1}<60 \%$ pred. and frequent exacerbations. In the TORCH trial, combination therapy was associated with an increased risk of pneumonia, but not with overall mortality (Evidence A) [58, 68-74].

The addition of a LABA/ICS combination to tiotropium is frequently used in severe to very severe COPD. This triple combination improves lung function and quality of life and may further reduce exacerbations compared to tiotropium monotherapy or LABA/ICS dual therapy $[75,76]$. 


\section{Antibiotics}

The use of antibiotics in stable disease (i.e. outside of exacerbations) is not recommended. A recent trial of daily azithromycin, a macrolide antibiotic, showed efficacy on exacerbation end points [77]. However, general use is not recommended until further studies confirm effectiveness and exclude relevant long-term side effects.

\section{Mucolytics}

A review article has recently been published about the effects of mucoactive therapy in COPD [78]. Most trials have been performed with $\mathrm{N}$-acetylcysteine or carbocysteine. Overall, the authors found a significant reduction in exacerbations and in the number of days with disability. Mucolytics were well tolerated and the number of adverse events was lower than with placebo. However, in the largest and best-designed study with $\mathrm{N}$-acetylcysteine in 523 patients with COPD, the reduction in exacerbations was only observed in patients not taking ICS [79]. The use of mucolytics is not generally recommended, but may be an option in COPD patients with frequent exacerbations.

\section{Immunostimulating Agents}

Immunostimulating agents made from bacterial extracts represent a class of medications whose potential benefit results from a nonspecific stimulation of the immune system.

A systematic review of the studies on the use of bacterial extracts in COPD patients has shown a reduction in the symptoms of COPD exacerbations but no reduction of the rate of the exacerbations [80].

\section{Vaccination}

\section{Influenza Vaccination}

Influenza vaccination can reduce lower-tract respiratory infections that require hospitalization or cause death (Evidence A) [81]. Vaccination does not increase consultations, corticosteroid prescriptions or exacerbations in subjects with asthma or COPD [82, 83]. The strains are adjusted annually for appropriate effectiveness and should be given each year in autumn (or possibly twice, in autumn and winter).

\section{Pneumococcal Vaccine}

The 23 -valent pneumococcal polysaccharide vaccine protects against invasive pneumococcal disease, such as bacteremia and meningitis, but does not reduce all-cause pneumonia. In a small study, a decreased rate of pneumo- nia was found only in younger people ( $<65$ years) and in those with severe airflow obstruction $\left(\mathrm{FEV}_{1}<40 \%\right)$ [84]. In spite of this weak evidence, the 23-valent pneumococcal polysaccharide vaccine is recommended for all sufferers of chronic lung disease (Evidence B). Results on the effect of a conjugated 13-valent pneumococcal vaccine in adults are not available for the time being.

\section{Oxygen Therapy}

It has been shown that the survival of patients with chronic respiratory failure due to COPD is improved by long-term oxygen administration ( $>15 \mathrm{~h}$ per day) (Evidence B) [85-87].

Long-term oxygen therapy [88] is indicated if the $\mathrm{PaO}_{2}$ is:

- at or below $7.3 \mathrm{kPa}(55 \mathrm{~mm} \mathrm{Hg})$ with or without hypercapnia confirmed twice over a 3-week period (Evidence $\mathrm{B}$ )

- between $7.3 \mathrm{kPa}(55 \mathrm{~mm} \mathrm{Hg})$ and $8.0 \mathrm{kPa}(59 \mathrm{~mm} \mathrm{Hg})$, if there is evidence of pulmonary hypertension or polycythemia (hematocrit $>55 \%$ ) (Evidence D).

Long-term oxygen therapy may be considered in:

- situative hypoxemia, i.e. hypoxemia $(<90 \%$ saturation) during sleep or during exercise.

The primary goal of oxygen therapy is to increase the baseline arterial partial pressure $\left(\mathrm{PaO}_{2}\right)$ to at least $8.0 \mathrm{kPa}$ $(60 \mathrm{~mm} \mathrm{Hg}$ ) or to achieve arterial oxygen saturation equal to or above $90 \%$. Smoking cessation is a requirement for long-term oxygen therapy. The prescription of oxygen should always include the source of supplemental oxygen (gas or liquid), the method of delivery (via nasal cannula or transtracheal), the duration of use ( $>15 \mathrm{~h}$ or, if possible, $24 \mathrm{~h}$ per day) and the flow rate at rest, during exercise and sleep. Oxygen given during exercise may increase walking distance and endurance most likely by optimizing oxygen delivery to the tissues and its utilization by muscles. However, there are no data to suggest that long-term oxygen therapy changes exercise capacity per se.

In the absence of symptoms of sleep apnea, there is no indication for specific sleep studies.

\section{Alpha-1-Antitrypsin Replacement}

Intravenous replacement with $\alpha_{1}$-antitrypsin (AAT) increases AAT levels and antielastase activity in serum and in bronchoalveolar lavage fluid [15]. Uncontrolled trials have shown positive effects with augmentation therapy in COPD patients with AAT deficiency. Two small, randomized, double-blind, placebo-controlled tri- 
als have investigated the efficacy of intravenous AAT augmentation therapy on emphysema progression using CT densitometry $[89,90]$. Data from these similar trials, the 2-center Danish-Dutch study $(\mathrm{n}=54)$ and the 3 -center EXACTLE study ( $\mathrm{n}=65)$, have been pooled to increase the statistical power [91]. All subjects, i.e. 60 under replacement and 59 in the placebo group, were assessed by a CT scan at baseline and after treatment, with a mean follow-up of approximately 2.5 years. The combined data, as analyzed by one of four analytical methods, showed a significantly reduced decline in lung density. However, clinical end points (decline of $\mathrm{FEV}_{1}$, exacerbation rate and quality of life) did not demonstrate statistical differences. Due to this and to a lack of accepted criteria to assess the efficiency of this costly treatment, a recommendation for AAT replacement cannot be given.

\section{Ventilatory Support}

Noninvasive ventilation in combination with longterm oxygen therapy may be used in a selected subset of patients, particularly in those with pronounced daytime hypercapnia. In patients with both COPD and obstructive sleep apnea, there are clear benefits from continuous positive airway pressure (CPAP) in relation to both survival and the risk of hospital admission $[92,93]$.

\section{Pulmonary Rehabilitation, Psychological Support and Nutrition}

\section{Rehabilitation}

Exercise capacity and the level of physical activity are strong prognostic factors in COPD. Pulmonary rehabilitation and maintenance of physical activity have the potential to improve exercise tolerance, to decrease dyspnea and anxiety and to reduce the number of hospitalizations (Evidence A) [94, 95]. Comprehensive pulmonary rehabilitation includes patient education, instruction for selfmanagement (action plans), nutritional counseling and exercise training. The type of exercise (stair climbing, walking, treadmill and bicycle ergometer) may vary and is best determined by patient preference. Interval exercise training is usually better tolerated by patients. Whether pulmonary rehabilitation is conducted in an inpatient or outpatient setting depends on local availability and a patient's preference and comorbidity. Pulmonary rehabilitation is also effective soon after exacerbations [96]. Comorbidities are not a contraindication for pulmonary re- habilitation [97]. The benefit in exercise performance and quality of life is maintained if patients follow a regular exercise program at home [98]. The routine use of respiratory muscle training cannot be recommended, but individual patients may benefit from this.

\section{Psychological Support}

COPD is a progressive disease that will eventually severely impair the patient's quality of life. Even with the best care, shortness of breath, once it starts occurring during daily activities, profoundly modifies family life, sexuality and social interaction. The patient becomes more isolated, dependent and depressed. This complex burden of suffering can be overwhelming, and a patient's coping mechanisms may be insufficient. The prevalence of anxiety and depression is higher in certain COPD patients and is associated with dyspnea and a reduced quality of life [99-101]. Exercise training and antidepressant drugs are often effective in ameliorating dyspnea and anxiety [102]. Pulmonary rehabilitation may decrease psychosocial morbidity even without specific psychological interventions [103].

\section{Nutrition}

Weight loss is a common feature in patients with advanced COPD. The clinical importance of weight loss, particularly of fat-free mass, and its adverse effects on physical performance and quality of life have been demonstrated [104]. Moreover, a low BMI is an independent predictor for increased mortality [105]. Although nutritional support in these patients seems logical, controlled trials have not shown significant effects of weight gain on lung function or exercise capacity in patients with stable COPD [106]. Supplementation may, however, improve the outcome of training in some patients [107].

\section{Invasive Interventions}

\section{Lung Volume Reduction Surgery}

Bullectomy, i.e. the removal of large bulla that compress the adjacent lung structures, is a well-established surgical procedure and can be performed thoracoscopically. It is effective in reducing dyspnea and improving lung function $[108,109]$. Lung volume reduction surgery (LVRS) reduces emphysematous parts of the lung to reduce hyperinflation. It is a palliative procedure which not only improves pulmonary function and exercise capacity in selected patients with severe hyperinflation, but has a major positive impact on quality of life for several years [110, 
111]. Patients with heterogeneous types of emphysema and low exercise capacity have the greatest improvement in pulmonary function after LVRS [112], but patients with homogeneous emphysema may also experience significantly better health status and lung function compared to with usual medical care - when high-risk candidates with an extremely low $\mathrm{FEV}_{1}$ and a homogeneous emphysema or a diffusing capacity of $<20 \%$ pred. were excluded.

\section{Bronchoscopic Lung Volume Reduction}

A range of different techniques such as endobronchial valves, coils, airway bypass, thermal vapor ablation and biological sealants have been employed in both homogeneous as well as heterogeneous types of emphysema. Carefully selected patients with very severe COPD may benefit from bronchoscopic lung volume reduction [113]. However, the currently available data on the efficacy and safety of different types of bronchoscopic lung volume reduction procedures are not conclusive and further data is therefore needed.

\section{Lung Transplantation}

The decision to proceed with lung transplantation for severe COPD is complex. There is plenty of evidence suggesting that functional capacity is improved following the procedure, but the presence of a survival benefit is less clear. It is important to define disease severity as precisely as possible in order to determine which patients have the most urgent need for lung transplantation and are likely to have the longest survival afterwards. Transplantation is usually deferred until the BODE index is 7 or higher, the $\mathrm{FEV}_{1}$ is $<20 \%$ pred., the diffusing capacity for carbon monoxide is $<20 \%$ pred. or the clinical course becomes more aggressive with life-threatening exacerbations. Since many patients with advanced COPD are older and affected by comorbidities, the selection of suitable transplant candidates is a particular challenge. Contraindications for lung transplantation are malignancies, renal or liver failure, drug abuse and emotional instability. It is essential to refer possible lung transplantation candidates for evaluation to a lung transplant center early enough [114-116].

\section{Exacerbation of COPD}

\section{Definition, Impact, Severity and Etiology}

An exacerbation, as defined by the GOLD, is 'an event in the natural course of the disease characterized by a change in the patient's baseline dyspnoea, cough and/or sputum that is beyond normal day to day variation, is acute in onset and may warrant a change in regular medication in a patient with underlying COPD' [117]. Exacerbations in COPD are characterized by a broad variation in clinical presentation and are triggered by several factors.

It has been recognized that there is a subgroup of COPD patients who experience frequent exacerbations ( $\geq 2$ per year). Recurrent exacerbations have a strong negative impact on quality of life, often lead to hospitalization and are associated with higher rates of morbidity and mortality in COPD. The association of several clinical features with frequent exacerbations has been demonstrated, including a higher degree of airway obstruction, an advanced GOLD stage or BODE category, the presence of chronic cough and sputum production, advanced age and clinical depression.

The current American Thoracic Society and European Respiratory Society guidelines provide a descriptive means of defining the severity of exacerbations [23]. The classification of exacerbation severity is thereby defined by the necessary extent of the acute medical intervention. Exacerbations are divided into 3 categories, level I with treatment at home, level II requiring hospitalization and level III requiring ICU admission for respiratory failure, respectively. The classification of exacerbations into types I-III according to the criteria by Anthonisen et al. [118] does not reflect disease severity but is often used to estimate the likelihood of a of COPD exacerbation having a bacterial cause.

Although less than $50 \%$ of exacerbations have a bacterial cause, the presence of bacteria detected by sputum examination varied between 17 and $87 \%$ in certain investigations. In recognition of these diagnostic limitations, sputum cultures should not be performed during most exacerbations. Only selected cases, e.g. patients with $\mathrm{FEV}_{1}<30 \%$ pred., extensive bronchiectasis, prior evidence of Gram-negative rods or contemporary or previous antibiotic therapy warrant sputum cultures at exacerbation (Evidence C).

\section{Therapy}

\section{Pharmacological Therapy}

Bronchodilators, systemic corticosteroids, antibiotic agents, oxygen and noninvasive positive-pressure ventilation are the most common therapeutic measures in exacerbations of COPD. 


\section{Bronchodilators}

Short-acting $\beta_{2}$ agonists are the cornerstone of the treatment of exacerbations of COPD (Evidence D). The addition of an anticholinergic is generally recommended (Evidence D).

\section{Glucocorticoids}

Several randomized, controlled trials suggest that systemic glucocorticoids in COPD exacerbations accelerate the recovery of $\mathrm{FEV}_{1}$, decrease the length of hospital stay and improve clinical outcome (Evidence A) [119]. The strongest treatment effect of steroids occurs probably within the first $72 \mathrm{~h}$ and it levels off thereafter, suggesting a lack of benefit beyond 5 days of treatment. Despite a lack of well-designed randomized trials evaluating the most effective steroid dose, we recommend oral steroids be administered once daily in doses of 20 to $60 \mathrm{mg}$ of prednisone [120] for 5-15 days (Evidence C).

\section{Antibiotics}

The role of antibiotics in the treatment of COPD exacerbations is much less prominent than the role of steroids $[121,122]$. Viral infections are known to be the most common cause of acute exacerbations in COPD. Paradoxically, viral exacerbations were associated with more severe exacerbations and more prolonged symptom recovery than nonviral exacerbations. However, there is currently no reliable method to clearly distinguish bacterial exacerbations from those due to other etiologies. General recommendations for antibiotic use are not uniform and are often based on less-evaluated clinical parameters. Taking the risk of antibiotic overuse into account, routine antibiotic use has to be examined critically in outpatient exacerbations which often occur with a high spontaneous recovery rate (Evidence C). Antibiotics may be prescribed to patients who have 3 cardinal symptoms: an increase in dyspnea, sputum volume and sputum purulence (Evidence B), and also to patients with severe exacerbation who are admitted to an ICU (Evidence A) [123]. The determination of serum procalcitonin was shown to reduce the use of antibiotics in COPD exacerbations and may be of value in the decision to use antibiotics (Evidence A) [124]. If antibiotics are deemed needed, a short treatment course of $\leq 5$ days is preferred, as these have an outcome equal to a conventional treatment with antibiotics of 7-10 days (Evidence C) [125]. Longer courses of antibiotics should be considered for patients with more severe exacerbations requiring a hospital admission or ICU stay and those with proven colonization or infection with Gram-negative rods.

The effectiveness of older first-line antibiotics (amoxicillin, ampicillin and doxycyclin) and the newer broadspectrum second-line antibiotics (amoxicillin/clavulanic acid, 2nd and 3rd generation cephalosporins and quinolones) is comparable with regard to mortality, microbial outcome and the rate of adverse events (Evidence C). Second-line agents might present a small benefit in patients with more severe disease or more common exacerbations (Evidence C). Currently, the choice of antibiotic agent should therefore be guided by a recent history of antibiotic use and local microbial resistance patterns.

\section{Oxygen}

Oxygen therapy should be considered in the treatment of severe COPD exacerbations (Evidence D). Oxygen should be titrated to provide adequate levels of oxygenation $\left(\mathrm{PaO}_{2}>8.0 \mathrm{kPa}\right.$ or $\left.\mathrm{SaO}_{2}>90 \%\right)$. It is reasonable to assess arterial blood gases within 30-60 min after the institution of oxygen therapy to exclude significant $\mathrm{CO}_{2}$ retention.

\section{Nonpharmacological Therapy}

Several randomized trials and meta-analyses indicated that noninvasive positive pressure ventilation improves important clinical outcomes, such as intubation rate, treatment failure and inhospital mortality in patients with an acute exacerbation complicated by hypercapnic acidosis (Evidence A) [126].

\section{Acknowledgment}

The authors thank Dr. E. Grebski for her help with the reference list.
References

\footnotetext{
1 Murray CJ, Lopez AD: Alternative projections of mortality and disability by cause 1990- 2020: Global Burden of Disease Study. Lancet 1997;349:1498-1504.

-2 Salvi SS, Barnes PJ: Chronic obstructive pulmonary disease in non-smokers. Lancet 2009;374:733-743.
}

\footnotetext{
3 Schikowski T, Sugiri D, Ranft U, Gehring U, Heinrich J, Wichmann HE, Krämer U: Longterm air pollution exposure and living close to busy roads are associated with COPD in women. Respir Res 2005;6:152.
} 
-4 Vogelmeier C, Buhl R, Criée CP, Gillissen A, Kardos P, Köhler D, Magnussen H, Morr H, Nowak D, Pfeiffer-Kascha D, Petro W, Rabe K, Schultz K, Sitter H, Teschler H, Welte $\mathrm{T}$, Wettengel R, Worth $\mathrm{H}$ : Leitlinie der Deutschen Atemwegsliga und der Deutschen Gesellschaft für Pneumologie zur Diagnostik und Therapie von Patienten mit chronisch obstruktiver Bronchitis und Lungenemphysem (COPD). Pneumologie 2007; 61:e1-e40.

$\checkmark 5$ O’Donnell DE, Hernandez P, Kaplan A, Aaron S, Bourbeau J, Marciniuk D, Balter M, Ford G, Gervais A, Lacasse Y, Maltais F, Road J, Rocker G, Sin D, Sinuff T, Voduc N: Canadian Thoracic Society recommendations for management of chronic obstructive pulmonary disease - 2008 update - highlights for primary care. Can Respir J 2008; 15(suppl A):1A-8A.

6 Chronic obstructive pulmonary disease: management of chronic obstructive pulmonary disease in adults in primary and secondary care. London, National Clinical Guideline Centre, 2010. http://guidance. nice.org.uk/CG101/Guidance/pdf/English.

-7 Diagnosis and management of stable chronic obstructive pulmonary disease: a clinical practice guideline update from the American College of Physicians, American College of Chest Physicians, American Thoracic Society, and European Respiratory Society. Ann Intern Med 2011;155:179-191.

8 The global strategy for diagnosis, management and prevention of COPD: GOLD. www.goldcopd.org (updated 2011).

-9 Russi EW, Leuenberger P, Brändli O, Frey JG, Grebski E, Gugger M, Paky A, Pons M, Karrer W, Kuhn M, Rochat T, Schibli R, Solèr M, Wacker J: Management of chronic obstructive pulmonary disease: the Swiss guidelines. Official Guidelines of the Swiss Respiratory Society. Swiss Med Wkly 2002;132:67-78.

10 Eisner MD, Anthonisen N, Coultas D, Kuenzli N, Perez-Padilla R, Postma D, Romieu I, Silverman EK, Balmes JR: An official American Thoracic Society public policy statement: novel risk factors and the global burden of chronic obstructive pulmonary disease. Am J Respir Crit Care Med 2010;182: 693-718.

-11 Lamprecht B, McBurnie MA, Vollmer WM, Gudmundsson G, Welte T, NizankowskaMogilnicka E, Studnicka M, Bateman E, Anto JM, Burney P, Mannino DM, Buist SA, BOLD Collaborative Research Group: COPD in never smokers: results form the population-based burden of obstructive lung disease study. Chest 2011;139:752-763.
12 Mehta AJ, Miedinger D, Keidel D, Bettschart R, Bircher A, Bridevaux PO, Curjuric I, Kromhout H, Rochat T, Rothe T, Russi EW, Schikowski T, Schindler C, Schwartz J, Turk A, Vermeulen R, Probst-Hensch N, Künzli $\mathrm{N}$, The SAPALDIA Team: Occupational exposure to dusts, gases, and fumes and incidence of chronic obstructive pulmonary disease in the Swiss Cohort Study on Air Pollution and Lung and Heart Diseases in Adults. Am J Respir Crit Care Med 2012;185:12921300.

13 Silva GE, Sherrill DL, Guerra S Barbee RA: Asthma as a risk factor for COPD in a longitudinal study. Chest 2004;126:59-65.

14 Stoller JK: Clinical features and natural history of severe alpha-1-antitrypsin deficiency. Chest 1997;111:123S-128S.

15 Stoller JK, Aboussouan LS: A review of alpha-1-antitrypsin deficiency. Am J Respir Crit Care Med 2012;185:246-259.

16 Smolonska J, Wijmenga C, Postma DS, Boezen HM: Meta-analyses on suspected chronic obstructive pulmonary disease genes: a summary of 20 years' research. Am J Respir Crit Care Med 2009;180:618-631.

17 Brutsche MH, Downs SH, Schindler C, Gerbase MW, Schwartz J, Frey M, Russi EW, Ackermann-Liebrich $U$, Leuenberger $P$ : Bronchial hyperresponsiveness and the development of asthma and COPD in asymptomatic individuals: SAPALDIA cohort study. Thorax 2006;61:671-677.

-18 de Marco R, Accordini S, Marcon A, Cerveri I, Antó JM, Gislason T, Heinrich J, Janson C, Jarvis D, Kuenzli N, Leynaert B, Sunyer J, Svanes C, Wjst M, Burney P, European Community Respiratory Health Survey (ECRHS): Risk factors for chronic obstructive pulmonary disease in a European cohort of young adults. Am J Respir Crit Care Med 2011;183: 891-897.

19 de Marco R, Accordini S, Cerveri I, Corsico A, Antó JM, Künzli N, Janson C, Sunyer J, Jarvis D, Chinn S, Vermeire P, Svanes C, Ackermann-Liebrich U, Gislason T, Heinrich J, Leynaert B, Neukirch F, Schouten JP, Wjst M, Burney P: Incidence of chronic obstructive pulmonary disease in a cohort of young adults according to the presence of chronic cough and phlegm. Am J Respir Crit Care Med 2007;175:32-39.

20 Bridevaux PO, Gerbase MW, Probst-Hensch NM, Schindler C, Gaspoz JM, Rochat T: Long-term decline in lung function, utilisation of care and quality of life in modified GOLD stage 1 COPD. Thorax 2008;63:768774.

21 Buist AS, McBurnie MA, Vollmer WM, Gillespie S, Burney P, Mannino DM, Menezes AM, Sullivan SD, Lee TA, Weiss KB, Jensen RL, Marks GB, Gulsvik A, NizankowskaMogilnicka E, BOLD Collaborative Research Group: International variation in the prevalence of COPD (the BOLD study): a population-based prevalence study. Lancet 2007;370:741-750.
22 Bridevaux PO, Probst-Hensch NM, Schindler C, Curjuric I, Felber Dietrich D, Braendli O, Brutsche M, Burdet L, Frey M, Gerbase MW, Ackermann-Liebrich U, Pons M, Tschopp JM, Rochat T, Russi EW: Prevalence of airflow obstruction in smokers and never smokers in Switzerland. Eur Respir J 2010;36:1259-1269.

23 Celli B, MacNee W, ATS/ERS Task Force: Standards for the diagnosis and treatment of patients with COPD: a summary of the ATS/ ERS position paper. Eur Respir J 2004;23: 932-946.

24 Bestall JC, Paul EA, Garrod R, Garnham R, Jones PW, Wedzicha JA: Usefulness of the Medical Research Council (MRC) dyspnoea scale as a measure of disability in patients with chronic obstructive pulmonary disease. Thorax 1999;54:581-586.

$\checkmark 25$ Jones PW, Harding G, Berry P, Wiklund I, Chen WH, Kline Leidy N: Development and first validation of the COPD Assessment Test. Eur Respir J 2009;34:648-654.

26 Hurst JR, Vestbo J, Anzueto A, Locantore N, Müllerova H, Tal-Singer R, Miller B, Lomas DA, Agusti A, Macnee W, Calverley P, Rennard S, Wouters EF, Wedzicha JA: Susceptibility to exacerbation in chronic obstructive pulmonary disease. N Engl J Med 2010;363: 1128-1138.

27 Barnes PJ, Celli BR: Systemic manifestations and comorbidities of COPD. Eur Respir J 2009;33:1165-1185.

28 Celli B, Cote C, Marin J, Casanova C, Montes de Oca M, Mendez RA, Pinto Plata V, Cabral $\mathrm{HJ}$ : The body mass index, airflow obstruction, dyspnea, and exercise capacity index in chronic obstructive pulmonary disease. $\mathrm{N}$ Engl J Med 2004;350:1005-1012.

29 Qaseem A, Wilt TJ, Weinberger SE, Hanania NA, Criner G, van der Molen T, Marciniuk DD, Denberg T, Schünemann H, Wedzicha W, MacDonald R, Shekelle P: Diagnosis and management of stable chronic obstructive pulmonary disease: a clinical practice guideline update from the American College of Physicians, American College of Chest Physicians, American Thoracic Society, and European Respiratory Society. Ann Intern Med 2011;155:179-191.

30 Yawn BP, Enright PL, Lemanske RF Jr, Israel E, Pace W, Wollan P, Boushey H: Spirometry can be done in family physicians' offices and alters clinical decisions in management of asthma and COPD. Chest 2007;132:11621168.

31 Leuppi JD, Miedinger D, Chhajed PN, Buess C, Schafroth S, Bucher HC, Tamm M: Quality of spirometry in primary care for case finding of airway obstruction in smokers. Respiration 2010;79:469-474. 
-32 Swanney MP, Ruppel G, Enright PL, Pedersen OF, Crapo RO, Miller MR, Jensen RL, Falaschetti E, Schouten JP, Hankinson JL, Stocks J, Quanjer PH: Using the lower limit of normal for the $\mathrm{FEV}_{1} / \mathrm{FVC}$ ratio reduces the misclassification of airway obstruction. Thorax 2008;63:1046-1051.

33 Celli BR, Halbert RJ: Point: should we abandon $\mathrm{FEV}_{1} / \mathrm{FVC}<0.70$ to detect airway obstruction? No. Chest 2010;138:1037-1043.

34 Enright P, Brusasco V: Counterpoint: should we abandon $\mathrm{FEV}_{1} / \mathrm{FVC}<0.70$ to detect airway obstruction? Yes. Chest 2010;138:10401044.

- 35 Pelkonen M, Notkola IL, Tukiainen H, Tervahauta $M$, Toumilehto J, Nissinen A: Smoking cessation, decline in pulmonary function and total mortality: a 30-year follow-up study among the Finnish cohorts of the Seven Countries Study. Thorax 2001;56:703707.

36 Chandler MA, Rennard SI: Smoking cessation. Chest 2010;137:428-435.

37 Humair JP, Cornuz J: Raucherentwöhnung. Basisdokumentation für Ärztinnen und Ärzte. Verbindungen der Schweizer Ärztinnen und Ärzte FMH und Bundesamt für Gesundheit (BAG), 2000.

-38 Anthonisen NR, Connett JE, Kiley JP, Altose MD, Bailey WC, Buist AS, Conway WA Jr, Enright PL, Kanner RE, O'Hara P: Effects of smoking intervention and the use of an inhaled anticholinergic bronchodilator on the rate of decline of $\mathrm{FEV}_{1}$. The Lung Health Study. JAMA 1994;272:1497-1505.

-39 Henningfield JE: Nicotine medications for smoking cessation. N Engl J Med 1995;333: 1196-1203.

-40 Jorenby DE, Leischow SJ, Nides MA, Rennard SI, Johnston JA, Hughes AR, Smith SS, Muramoto ML, Daughton DM, Doan K, Fiore MC, Baker TB: A controlled trial of sustained-release bupropion, a nicotine patch, or both for smoking cessation. N Engl J Med 1999;340:685-691.

-41 Silagy C, Mant D, Fowler G, Lodge M: Metaanalysis on efficacy of nicotine replacement therapies in smoking cessation. Lancet 1994; 343:139-142.

-42 Tashkin D, Kanner R, Bailey W, Buist S, Anderson P, Nides M, Gonzales D, Dozier G, Patel MK, Jamerson B: Smoking cessation in patients with chronic obstructive pulmonary disease: a double-blind, placebo-controlled, randomised trial. Lancet 2001;357: 1571-1575.

-43 Strassmann R, Bausch B, Spaar A, Kleijnen J, Braendli O, Puhan MA: Smoking cessation interventions in COPD: a network metaanalysis of randomised trials. Eur Respir J 2009;34:634-640.

44 Faessel H, Ravva P, Williams K: Pharmacokinetics, safety, and tolerability of varenicline in healthy adolescent smokers: a multicenter, randomized, double-blind, placebocontrolled, parallel-group study. Clin Ther 2009;31:177-189.
45 Becklake MR: Occupational exposures: evidence for a causal association with chronic obstructive pulmonary disease. Am Rev Respir Dis 1989;140:S85-S91.

46 Heffner JE, Fahy B, Hilling L, Barbieri C: Outcomes of advance directive education of pulmonary rehabilitation patients. Am J Respir Crit Care Med 1997;155:1055-1059.

47 Stewart MA: Effective physician-patient communication and health outcomes: a review. CMAJ 1995;152:1423-1433.

48 Bischoff EW, Hamd DH, Sedeno M, Benedetti A, Schermer TR, Bernard S, Maltais F, Bourbeau J: Effects of written action plan adherence on COPD exacerbation recovery. Thorax 2011;66:26-31.

49 Fan VS, Gaziano JM, Lew R, Bourbeau J, Adams SG, Leatherman S, Thwin SS, Huang GD, Robbins R, Sriram PS, Sharafkhaneh A, Mador MJ, Sarosi G, Panos RJ, Rastogi P, Wagner TH, Mazzuca SA, Shannon C, Colling C, Liang MH, Stoller JK, Fiore L, Niewoehner DE: A comprehensive care management program to prevent chronic obstructive pulmonary disease hospitalizations: a randomized, controlled trial. Ann Intern Med 2012;156:673-683.

50 Littner MR, Ilowite JS, Tashkin DP, Friedman M, Serby CW, Menjoge SS, Witek TJ Jr: Long-acting bronchodilation with once-daily dosing of tiotropium (Spiriva) in stable chronic obstructive pulmonary disease. Am J Respir Crit Care Med 2000;161:1136-1142.

51 Karner C, Chong J, Poole P: Tiotropium versus placebo for chronic obstructive pulmonary disease. Cochrane Database Syst Rev 2012;7:CD009285.

52 Tashkin DP, Celli B, Senn S, Burkhart D, Kesten S, Menjoge S, Decramer M, UPLIFT Study Investigators: A 4-year trial of tiotropium in chronic obstructive pulmonary disease. N Engl J Med 2008;359:1543-1554.

53 Vogelmeier C, Hederer B, Glaab T, Schmidt H, Rutten-van Mölken MP, Beeh KM, Rabe KF, Fabbri LM, POET-COPD Investigators: Tiotropium versus salmeterol for the prevention of exacerbations of COPD. N Engl J Med 2011;364:1093-1103.

54 Singh S, Loke YK, Furberg CD: Inhaled anticholinergics and risk of major adverse cardiovascular events in patients with chronic obstructive pulmonary disease: a systemic review and meta-analysis. JAMA 2008;300: 1439-1450.

55 Michele TM, Pinheiro S, Iyasu S: The safety of tiotropium - the FDA's conclusions. N Engl J Med 2010;363:1097-1099.

56 Dahl R, Chung KF, Buhl R, Magnussen H, Nonikov V, Jack D, Bleasdale P, Owen R, Higgins M, Kramer B, INVOLVE Study: Efficacy of a new once-daily long-acting inhaled beta2-agonist indacaterol versus twice-daily formoterol in COPD. Thorax 2010;65:473-479.
57 Buhl R, Dunn LJ, Disdier C, Lassen C, Amos C, Henley M, Kramer B, INTENSITY Study Investigators: Blinded 12-week comparison of once-daily indacaterol and tiotropium in COPD. Eur Respir J 2011;38:797-803.

58 Calverley PMA, Anderson JA, Celli B, Ferguson GT, Jenkins C, Jones PW, Yates JC, Vestbo J, TORCH investigators: Salmeterol and fluticasone propionate and survival in chronic obstructive pulmonary disease. $\mathrm{N}$ Engl J Med 2007;356:775-798.

59 Aubier M, Barnes PJ: Theophylline and phosphodiesterase inhibitors. Eur Respir J 1995;8:347-348.

60 Calverley PM, Rabe KF, Goehring UM, Kristiansen S, Fabbri LM, Martinez FJ: Roflumilast in symptomatic chronic obstructive pulmonary disease. Lancet 2009;374:685-694.

-61 Fabbri LM, Calverley PM, Izquierdo-Alonso JL, Bundschuh DS, Brose M, Martinez FJ, Rabe KF: Roflumilast in moderate-to-severe chronic obstructive pulmonary disease treated with long-acting bronchodilators. Lancet 2009;374:695-703.

-62 Callahan CM, Dittus RS, Katz BP: Oral corticosteroid therapy for patients with stable chronic obstructive pulmonary disease. A meta-analysis. Ann Intern Med 1991;114: 216-223.

63 Postma DS, Steenhuis EJ, van der Weele LT, Sluiter HJ: Severe chronic airflow obstruction: can corticosteroids slow down progression? Eur J Respir Dis 1985;67:56-64.

64 Postma DS, Peters I, Steenhuis EJ, Sluiter HJ: Moderately severe chronic airflow obstruction. Can corticosteroids slow down obstruction? Eur Respir J 1988;1:22-26.

65 Decramer M, de Bock V, Dom R: Functional and histologic picture of steroid-induced myopathy in chronic obstructive pulmonary disease. Am J Respir Crit Care Med 1996;153: 1958-1964.

66 Gosselink R, Troosters T, Decramer M: Peripheral muscle weakness contributes to exercise limitation in COPD. Am J Respir Crit Care Med 1996;153:976-980.

67 Senderovitz T, Vestbo J, Frandsen J, Maltbaek N, Norgaard M, Nielsen C, Kampmann JP: Steroid reversibility test followed by inhaled budesonide or placebo in outpatients with stable chronic obstructive pulmonary disease. Respir Med 1999;93:715-718.

68 Sin DD, Tashkin D, Zhang X, Radner F, Sjöbring U, Thorén A, Calverley PM, Rennard SI: Budenoside and the risk of pneumonia: a meta-analysis of individual patient data. Lancet 2009;374:712-719.

69 Paggiaro PL, Dahle R, Bakran I, Frith L, Hollingworth K, Efthimiou J: Multicentre randomised placebo-controlled trial of inhaled fluticasone propionate in patients with chronic obstructive pulmonary disease. International COPD Study Group. Lancet 1998;351:773-780. 
70 Vestbo J, Sorensen T, Lange P, Brix A, Torre P, Viskum K: Long-term effect of inhaled budesonide in mild and moderate chronic obstructive pulmonary disease: a randomised controlled trial. Lancet 1999;353:1819-1823.

-71 Pauwels RA, Lofdahl CG, Laitinen LA, Schouten JP, Postma DS, Pride NB, Ohlsson SV: Long-term treatment with inhaled budesonide in persons with mild chronic obstructive pulmonary disease who continue smoking. N Engl J Med 1999;340:1948-1953.

72 Burge PS, Calverley PM, Jones PW, Spencer S, Anderson JA, Maslen TK: Randomised, double blind, placebo controlled study of fluticasone propionate in patients with moderate to severe chronic obstructive pulmonary disease: the ISOLDE trial. BMJ 2000; 320:1297-1303.

-73 Barnes PJ: Inhaled corticosteroids are not beneficial in chronic obstructive pulmonary disease. Am J Respir Crit Care Med 2000;161: 342-344.

-74 van Grunsven PM, van Schayck CP, Derenne JP, Kerstjens HA, Renkema TE, Postma DS, Similowski T, Akkermans RP, Pasker-de Jong PC, Dekhuijzen PN, van Herwaarden CL, van Weel C: Long term effects of inhaled corticosteroids in chronic obstructive pulmonary disease: a meta-analysis. Thorax 1999;54:7-14.

-75 Rodrigo GJ, Plaza V, Castro-Rodríguez JA: Comparison of three combined pharmacological approaches with tiotropium monotherapy in stable moderate to severe COPD: a systematic review. Pulm Pharmacol Ther 2012;25:40-47.

76 Ohar JA, Donohue JF: Mono- and combination therapy of long-acting bronchodilators and inhaled corticosteroids in advanced COPD. Semin Respir Crit Care Med 2010;31: 321-333.

-77 Albert RK: Azithromycin for prevention of exacerbations of COPD. N Engl J Med 2011; 365:689-698.

78 Decramer M, Janssens W: Mucoactive therapy in COPD. Eur Resp Rev 2010;19:134140.

-79 Decramer M, Rutten-Van Mölken M, Dekhuijzen PN, Troosters T, van Herwaarden C, Pellegrino R, van Schayck CP, Olivieri D, Del Donno M, De Backer W, Lankhorst I, Ardia A: Effects of N-acetylcysteine on outcomes in chronic obstructive pulmonary disease (Bronchitis Randomized on NAC Cost-Utility Study, BRONCUS): a randomised placebo-controlled trial. Lancet 2005;365:1552-1560.

-80 Steurer-Stey C, Bachmann LM, Steurer J, Tramèr MR: Oral purified bacterial extracts in chronic bronchitis and COPD: systematic review. Chest 2004;126:1645-1655.

81 Wongsurakiat P, Maranetra KN, Wasi C, Kositanont U, Dejsomritrutai W, Charoenratanaku S: Acute respiratory illness in patients with COPD and the effectiveness of influenza vaccination: a randomized controlled study. Chest 2004;125:2011-2020.
82 Poole P, Chacko EE, Wood-Baker R, Cates $\mathrm{CJ}$ : Influenza vaccine for patients with chronic obstructive pulmonary disease. Cochrane Database Syst Rev 2006;CD002733.

83 Tata LJ, West J, Harrison T, Farrington P, Smith C, Hubbard R: Does influenza vaccination increase consultations, corticosteroid prescriptions, or exacerbations in subjects with asthma or chronic obstructive pulmonary disease? Thorax 2003;58:835-839.

84 Alfageme I, Vazquez R, Reyes N, Muñoz J, Fernández A, Hernandez M, Merino M, Perez J, Lima J: Clinical efficacy of anti-pneumococcal vaccination in patients with COPD. Thorax 2006;61:189-195.

-85 Nocturnal Oxygen Therapy Trial Group: Continuous or nocturnal oxygen therapy in hypoxemic chronic obstructive lung disease: a clinical trial. Ann Intern Med 1980;93:391398.

86 Report of the Medical Research Council Working Party: Long term domiciliary oxygen therapy in chronic hypoxic cor pulmonale complicating chronic bronchitis and emphysema. Lancet 1981;1:681-686.

87 Zielinski J, Tobiasz M, Hawrylkiewicz I, Sliwinski P, Palasiewicz G: Effects of long-term oxygen therapy on pulmonary hemodynamics in COPD patients: a 6-year prospective study. Chest 1998;113:65-70.

88 Guidelines for long-term home oxygen therapy in patients with chronic respiratory insufficiency. Swiss Society for Tuberculosis and Lung Diseases Control and Swiss Society of Pneumology. Schweiz Med Wochenschr 1997; 127:871-875.

89 Dirksen A, Dijkman JH, Madsen F, Stoel B, Hutchison DC, Ulrik CS, Skovgaard LT, Kok-Jensen A, Rudolphus A, Seersholm N, Vrooman HA, Reiber JH, Hansen NC, Heckscher T, Viskum K, Stolk J: A randomized clinical trial of alpha-1-antitrypsin augmentation therapy. Am J Respir Crit Care Med 1999; 160:1468-1472.

90 Dirksen A, Piitulainen E, Parr DG, Deng C, Wencker M, Shaker SB, Stockley RA: Exploring the role of CT densitometry: a randomized study of augmentation therapy in alfa-1 antitrypsin defiency. Eur Respir J 2009;33: 1345-1353.

91 Stockley RA, Parr DG, Piitulainen E, Stolk J, Stoel BC, Dirksen A: Therapeutic efficacy of alpha-1 antitrypsin augmentation therapy on the loss of lung tissue: an integrated analysis of 2 randomised clinical trials using computed tomography densitometry. Respir Res 2010;11:136.

92 McEvoy RD, Pierce RJ, Hillman D, Esterman A, Ellis EE, Catcheside PG, O’Donoghue FJ, Barnes DJ, Grunstein RR: Nocturnal noninvasive nasal ventilation in stable hypercapnic COPD: a randomized controlled trial. Tho$\operatorname{rax} 2009 ; 64: 561-566$.
$\$ 93$ Marin JM, Soriano JB, Carrizo SJ, Boldova A, Celli BR: Outcomes in patients with chronic obstructive pulmonary disease and obstructive sleep apnea: the overlap syndrome. Am J Respir Crit Care Med 2010; 182:325-331.

94 Lacasse Y; Goldstein R, Lasserson T, Martin $S$ : Pulmonary rehabilitation for chronic obstructive pulmonary disease. Cochrane Database Syst Rev 2006;CD003793.

95 Garcia-Aymerich J, Lange P, Benet M, Schnohr P, Antó JM: Regular physical activity reduces hospital admission and mortality in chronic obstructive pulmonary disease: a population based cohort study. Thorax 2006;61:772-778.

96 Puhan MA, Gimeno-Santos E, Scharplatz M, Troosters T, Walters EH, Steurer J: Pulmonary rehabilitation following exacerbations of chronic obstructive pulmonary disease. Cochrane Database Syst Rev 2011;CD005305.

97 Crisafulli E, Gorgone P, Vagaggini B, Paganai M, Rossi G, Costa F, Guariello V, Paggiaro $\mathrm{P}$, Chetta $\mathrm{A}$, de Blasio $\mathrm{F}$, Olivieri $\mathrm{D}$, Fabbri LM, Clini EM: Efficacy in standard rehabilitation in COPD outpatients with comorbidities. Eur Resp J 2010;36:1042-1048.

\$8 Spencer LM, Alison JA, McKeough ZJ Maintaining benefits following pulmonary rehabilitation: a randomized controlled trial. Eur Resp J 2010;35:571-577.

$\$ 99$ Von Leupoldt A, Taube K, Lehmann K, Fritzsche A, Magnussen $\mathrm{H}$ : The impact of anxiety and depression on outcomes of pulmonary rehabilitation in patients with COPD. Chest 2011;140:730-736

100 Maurer J, Rebbapraganda V, Borson S, Goldstein R, Kunik ME, Yohannes AM, Hanania NA: Anxiety and depression in COPD: current understanding, unanswered questions and research needs. Chest 2008; 134;43S-56S.

$101 \mathrm{Xu} \mathrm{W}$, Collet JP, Shapiro S, Lin Y, Platt RW, Wang C, Bourbeau J: Independent effect of depression and anxiety on chronic obstructive pulmonary disease exacerbations and hospitalizations. Am J Respir Crit Care Med 2008;178:913-920.

102 Hill K, Geist R, Goldstein RS, Lacasse Y: Anxiety and depression in end-stage COPD. Eur Respir J 2008;31:667-677.

103 Güell R, Resqueti V, Sangenis M, Morante F, Bernardi M, Casan P, Guyatt G: Impact of pulmonary rehabilitation on psychosocial morbidity in patients with severe COPD. Chest 2006;129:899-904.

104 Shoup R, Dalsky G, Warner S, Davies M, Connors M, Khan M, et al: Body composition and health-related quality of life in patients with obstructive airways disease. Eur Respir J 1997;10:1576-1580.

105 Schols AM, Slangen J, Volovics L, Wouters FM: Weight loss is a reversible factor in the prognosis of chronic obstructive pulmonary disease. Am J Respir Crit Care Med 1998;157:1791-1797. 
106 Ferreira IM, Brooks D, Lacasse Y, Goldstein RS: Nutritional support for individuals with COPD: a meta-analysis. Chest 2000; 117:672-678.

107 Steiner MC, Barton RL, Singh SJ, Morgan MDL: Nutritional enhancement of exercise performance in chronic obstructive pulmonary disease: a randomised controlled trial. Thorax 2003;58:745-761.

108 Laros CD, Gelissen HJ, Bergstein PG, Van den Bosch JM, Vanderschueren RG, Westermann CJ, Knaepen PJ: Bullectomy for giant bullae in emphysema. J Thorac Cardiovasc Surg 1986;91:63-70.

109 Tiong LU, Davies R, Gibson PG, Hensley MJ, Hepworth R, Lasserson TJ, Smith B: Lung volume reduction surgery for diffuse emphysema. Cochrane Database Syst Rev 2006;CD001001.

-110 Cooper JD, Trulock EP, Triantafillou AN, Patterson GA, Pohl MS, Deloney PA, Sundaresan RS, Roper CL: Bilateral pneumectomy (volume reduction) for chronic obstructive pulmonary disease. J Thorac Cardiovasc Surg 1995;109:106-116.

-111 Weder W, Tutic M, Lardinois D, Jungraithmayr W, Hillinger S, Russi E.W, Bloch KE: Persistent benefit from lung volume reduction surgery in patients with homogeneous emphysema. Ann Thorac Surg 2009;87: 229-236.

112 National Emphysema Treatment Trial Research Group: A randomized trial comparing lung-volume-reduction surgery with medical therapy for severe emphysema. $\mathrm{N}$ Engl J Med 2003;348:2059-2073.

113 Gasparini S, Zuccatosta L, Bonifazi M, Bolliger CT: Bronchoscopic treatment of emphysema: state of the art. Respiration 2012; $84: 250-263$.
114 Orens JB, Estenne M, Arcasoy S, Conte JV, Corris P, Egan JJ, Egan T, Keshavjee S, Knoop C, Kotloff R, Martinez FJ, Nathan S, Palmer S, Patterson A, Singer L, Snell G, Studer S, Vachiery JL, Glanville AR: International guidelines for the selection of lung transplant candidates: 2006 update - a consensus report from the Pulmonary Scientific Council of the International Society for Heart and Lung Transplantation. J Heart Lung Transplant 2006;25:745-755.

115 Thabut G, Ravaud P, Christie JD, Castier Y, Fournier M, Mal H, Leseche G, Porcher R: Determinants of the survival benefit of lung transplantation in patients with chronic obstructive pulmonary disease. Am J Respir Crit Care Med 2008;177:11561163.

116 Eskander A, Waddell TK, Faughnan ME, Chowdhury N, Singer LG: BODE index and quality of life in advanced chronic obstructive pulmonary disease before and after lung transplantation. J Heart Lung Transplant 2011;30:1334-1341.

117 Gold PM: The 2007 GOLD Guidelines: a comprehensive care framework. Respir Care 2009;54:1040-1049.

118 Anthonisen NR, Manfreda J, Warren CP, Hershfield ES, Harding GK, Nelson NA: Antibiotic therapy in exacerbations of chronic obstructive pulmonary disease. Ann Intern Med 1987;106:196-204.

119 Davies L, Angus RM, Calverley PM: Oral corticosteroids in patients admitted to hospital with exacerbations of chronic obstructive pulmonary disease: a prospective randomised controlled trial. Lancet 1999; 354:456-460.
120 Niewoehner DE, Erbland ML, Deupree RH, Collins D, Gross NJ, Light RW, Anderson P, Morgan NA: Effect of systemic glucocorticoids on exacerbations of chronic obstructive pulmonary disease. Department of Veterans Affairs Cooperative Study Group. N Engl J Med 1999;340:1941-1947.

121 Scherr A, Blasi F, Stolz D: An update on COPD exacerbations. Minerva Pneumologica 2011;50:129-146.

122 Daniels JM, Snijders D, de Graaff CS, Vlaspolder F, Jansen HM, Boersma WG: Antibiotics in addition to systemic corticosteroids for acute exacerbations of chronic obstructive pulmonary disease. Am J Respir Crit Care Med 2010;181:150-157.

123 Nouira S, Marghli S, Belghith M, Besbes L, Elatrous S, Abroug F: Once daily oral ofloxacin in chronic obstructive pulmonary disease exacerbation requiring mechanical ventilation: a randomised placebo-controlled trial. Lancet 2001;358:2020-2025.

124 Stolz D, Christ-Crain M, Bingisser R, Leuppi J, Miedinger D, Müller C, Huber P, Müller B, Tamm M: Antibiotic treatment of exacerbations of COPD: a randomized, controlled trial comparing procalcitonin guidance with standard therapy. Chest 2007;131:9-19.

125 El Moussaoui R, Roede BM, Speelman P, Bresser P, Prins JM, Bossuyt PM: Shortcourse antibiotic treatment in acute exacerbations of chronic bronchitis and COPD: a meta-analysis of double-blind studies. Thorax 2008;63:415-422.

126 Ram FS, Picot J, Lightowler J, Wedzicha JA: Non-invasive positive pressure ventilation for treatment of respiratory failure due to exacerbations of chronic obstructive pulmonary disease. Cochrane Database Syst Rev 2004;CD004104. 